\title{
The unusual high number of chromosomes signals rare multiple fission events in the Polynemidae (Carangaria, Teleostei)
}

\author{
W.F. Molina ${ }^{1}$, M.B. Cioffi ${ }^{2}$, R.X. Soares ${ }^{1}$, A.T. Borges ${ }^{1}$, \\ G.W.W.F. Costa ${ }^{1}$ and L.A.C. Bertollo ${ }^{2}$ \\ ${ }^{1}$ Departamento de Biologia Celular e Genética, Centro de Biociências, \\ Universidade Federal do Rio Grande do Norte (UFRN), Natal, RN, Brasil \\ ${ }^{2}$ Departamento de Genética e Evolução, Universidade Federal de São Carlos \\ (UFSCar), São Carlos, SP, Brasil
}

Corresponding author: W.F. Molina

E-mail: molinawf@yahoo.com.br

Genet. Mol. Res. 20 (1): gmr18701

Received January 06, 2021

Accepted January 28, 2021

Published February 28, 2021

DOI http://dx.doi.org/10.4238/gmr18701

\begin{abstract}
Polynemidae, commonly known as threadfins, are important fishing and aquaculture species. This is a peculiar fish group that is morphologically characterized by long tactile filaments of the pectoral fins. Although inserted in the Percomorpha, its relationships with other groups of this clade are uncertain. Cytogenetic investigations have helped clarify various evolutionary aspects of marine fish groups, including stock delimitation, speciation, taxonomy, hybridization, phylogenetic relationship, sex chromosomes, and genome changes. However, the chromosomal characteristics of threadfins are still unknown. We investigated the chromosomal features of two cryptic species, Polydactylus virginicus and $P$. oligodon found in Northeast Brazilian coastal waters (Tropical Southwestern Atlantic region). Cytogenetic data were obtained by conventional staining (Giemsa and fluorochrome staining, C-banding and Ag-NORs techniques) and molecular cytogenetic analyses through fluorescent in situ hybridization using rDNA probes (18S and 5S rDNA). The two species have similar karyotypes at the macro and microstructural levels. An unexpected high diploid number was found, with $2 \mathrm{n}=58$ acrocentric chromosomes, including four
\end{abstract}


microchromosome pairs. The expanded karyotypes are a synapomorphy for these species, likely resulting from sharing at least five chromosome fissions from a basal karyotype with $2 \mathrm{n}=48$. Besides the macrostructural karyotype similarities, the Ag-NOR/GCrich/18S rDNA (chromosome 19) and 5S rDNA (chromosome 20) loci have an identical organization in apparently homeolog chromosomes of these species, suggesting the conservation of large syntenic chromosomal regions. We conclude that although chromosome fissions are very rare events among other Carangaria fish, they played an important disruptive role in the evolution of some species of Polynemidae.

Key words: Karyotype evolution; Chromosome fission; Threadfins; rDNA; Microchromosomes

\section{INTRODUCTION}

The Polynemidae family comprises species commonly known as threadfins, due to peculiar tactile filaments in their pectoral fins. They are typically found at sand and mudflats, where they feed on benthic invertebrates, in the subtropical waters of oceans worldwide, mainly in coastal and estuarine regions, being important resources for fishing and aquaculture in some countries (Motomura, 2004; Nelson et al., 2016). This family includes eight genera and 42 species, of which 21 belong to the Polydactylus genus (Fricke et al., 2020; Froese and Pauly, 2020).

Three Polydactylus species occur in the western Atlantic Ocean and in the Brazilian coast, among them $P$. oligodon and $P$. virginicus are largely distributed along the Brazilian coast, while P. octonemus is restricted to the North coast (Menezes and Figueiredo, 1985; Carpenter, 2002; Motomura, 2004). Morphologically, P. oligodon and P. virginicus are very similar to each other, their distinction only possible based on specific serial characters (such as lateral-line scales) (Motomura, 2004).

Threadfins are included in the large Percomorpha clade, composed of 30 orders (Betancur-R et al., 2013a), encompassing most of the extant fish diversity ( $>17,000$ species). Till now, the phylogenetic relationships of the Polynemidae are very controversial and uncertain, and this family has been found to be related to numerous distinct fish groups. Morphological traits associate this family with the Sphyraenidae, Mugilidae and Atherinidae (Gosline, 1968), and Sciaenidae (Johnson, 1993; Kang et al., 2017; Presti et al., 2020). On the contrary, molecular data suggest its relatedness to the Menidae and Lactariidae (Betancur-R et al., 2013a; Sanciangco et al., 2015), and Pleuronectiformes and Carangiformes (Harrington et al., 2016; Hughes et al., 2018).

In addition to morphological and molecular data, cytogenetics has also provided useful approaches to better understand the evolutionary history of several freshwater and marine fishes (Cioffi et al., 2018; Motta-Neto et al., 2019). However, only one Polynemidae species has some chromosomal information currently available (Khuda-Bukhsh and Barat, 1987). Consequently, we used conventional cytogenetic analyses (Giemsa staining and AgNOR, fluorochrome and heterochromatin banding), and in situ hybridization (ISH) procedures with ribosomal gene probes on two species of the genus Polydactylus from the 
Southwestern Atlantic. This study was intended to help understand the chromosomal characteristics and evolution of the threadfins and their relationships with other fish groups.

\section{MATERIAL AND METHODS}

\section{Specimens, mitotic preparation, and chromosome banding}

Adult individuals of Polydactylus virginicus ( $\mathrm{n}=11$, six males and five females) and Polydactylus oligodon ( $\mathrm{n}=5$, three males and two females) were caught with a hook and line on the coast of the State of Rio Grande do Norte (Touros Municipality; 05 11 '56"S, $35^{\circ} 27^{\prime} 39^{\prime \prime} \mathrm{W}$ ), in the Northeast region of Brazil. All field and laboratory protocols used in this study, including specimen sampling, were approved by the Ethics Committee on the use of animals at the Federal University of Rio Grande do Norte (Proc. \# 44-15). Collections were authorized by the Chico Mendes Institute for Biodiversity Conservation (ICMBio), System of Authorization, and Information about Biodiversity (SISBIO-Licenses No. 191351,131360-1 and 27027-2).

The specimens were kept in aquaria and submitted to mitotic stimulation through intramuscular injection of bacterial and fungal antigens complexes, for a period of 24 to 48 h (Molina et al., 2010). Mitotic chromosomes were obtained from renal tissue cells, according to in vitro short-term culture technique (Gold et al., 1990). Cell suspensions were dropped onto slides covered with a thin film of heated water $\left(60^{\circ} \mathrm{C}\right)$, and air-dried. The nucleolus organizer regions (NORs) and the heterochromatin content were identified according to Howell and Black (1980) and Sumner (1972) protocols, respectively. Sequential staining with Chromomycin $\mathrm{A}_{3}\left(\mathrm{CMA}_{3}\right)$ and DAPI (4', 6-diamidino-2phenylindol) fluorochromes (Schweizer, 1976) were also performed.

\section{Fluorescence in situ hybridization - FISH}

\section{DNA probes}

5S rDNA ( $200 \mathrm{pb})$ and 18S rDNA (1400 pb) probes were obtained by PCR from nuclear DNA of Rachycentron canadum (Teleostei), using primers A 5'-TAC GCC CGA TCT CGT CCG ATC-3' and B 5'-CAG GCT GGT ATG GCC GTA AGC-3' (Pendás et al., 1994), and NS1 5'-GTA GTC ATA TGC TTG TCT C-3' and NS8 5'-TCC GCA GGT TCA CCT ACG GA-3' (White et al., 1990), respectively. The 5S rDNA probe was labeled with biotin-14-dATP and the 18S rDNA with digoxigenin-11-dUTP (Roche, Mannheim, Germany), by nick translation, following manufacturer's recommendations.

\section{Hybridization}

FISH followed the procedure described by Pinkel et al. (1986). Metaphase chromosomes were treated with RNAse $(20 \mu \mathrm{g} / \mathrm{mL}$ in $2 \times \mathrm{xSC})$ at $37^{\circ} \mathrm{C}$ for $1 \mathrm{~h}$ and with pepsin $(0.005 \%$ in $10 \mathrm{mM} \mathrm{HCl})$ at $37^{\circ} \mathrm{C}$ for $10 \mathrm{~min}$, fixed with $1 \%$ formaldehyde for $10 \mathrm{~min}$ and then dehydrated in an alcohol series $(70 \% / 85 \% / 100 \%)$ for 5 min each. The slides with metaphase chromosomes were incubated in $70 \%$ formamide $/ 2 \mathrm{xSSC}$ at $72^{\circ} \mathrm{C}$, for $5 \mathrm{~min}$. The hybridization step was performed using the hybridization solution $(50 \%$ formamide, $2 \mathrm{xSSC}$, 
and $10 \%$ dextran sulfate) and the denatured probe $(5 \mathrm{ng} / \mu \mathrm{L})$, with a final volume of $30 \mu \mathrm{L}$, for $16 \mathrm{~h}$ at $37^{\circ} \mathrm{C}$.

Post-hybridization washes were performed with $15 \%$ formamide $/ 0.2 \mathrm{xSSC}$ at $42^{\circ} \mathrm{C}$, for $20 \mathrm{~min}$, plus $0.1 \mathrm{xSSC}$ at $60^{\circ} \mathrm{C}$ for $15 \mathrm{~min}$ and in $0.5 \% / 4 \mathrm{xSSC}$ Tween 20 for $5 \mathrm{~min}$, at room temperature. The hybridization signals were detected using rhodamine-conjugated anti-digoxigenin for the 18S rDNA, and FITC-conjugated streptavidin (Vector, Burlingame, USA) for the 5S rDNA, and the chromosomes were counterstained with Vectashield/DAPI $(1,5 \mu \mathrm{g} / \mathrm{ml})$ (Vector, Burlingame, USA).

\section{Chromosome analyses}

At least 30 metaphases of each individual were analyzed and the best spreads were photographed in an Olympus ${ }^{\mathrm{TM}} \mathrm{BX} 51$ epifluorescence microscope coupled to the digital image capture system Olympus DP73 (Olympus Corporation, Ishikawa, Japan), using the cellSens software (Version 1.9 Digital, Tokyo, Kanto, Japan). Chromosomes were classified as metacentric (m), submetacentric (sm), subtelocentric (st), or acrocentric (a), according to their arms ratio (Levan et al., 1964).

\section{RESULTS}

Polydactylus virginicus and $P$. oligodon present similar karyotypes, composed by $2 \mathrm{n}=58$ acrocentric chromosomes, the four smallest pairs consisting of microchromosomes $(<1 \mu \mathrm{m})$ with conspicuous differences in size in respect to the other ones (Figure 1). Besides both species also show similar organization patterns of the chromosomal regions analyzed. The Ag-NORs coincide with GC-rich secondary constrictions in the pericentromeric position of the long arm of the chromosome pair 24. The heterochromatin is mainly distributed in the centromeric regions, but also occupying an interstitial position in some chromosome pairs (Figure 1).

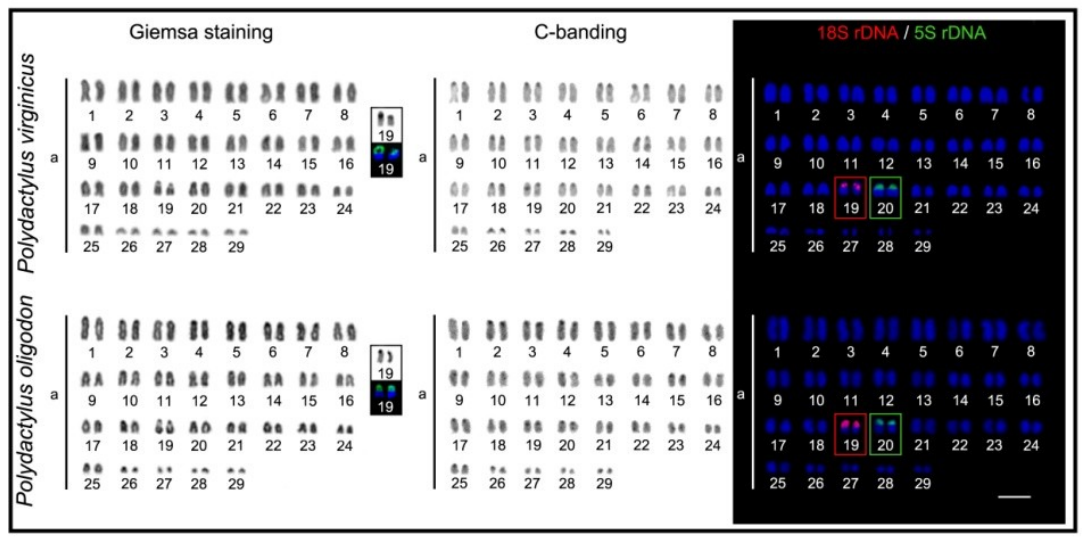

Figure 1. Karyotypes of Polydactylus virginicus and Polydactylus oligodon, after Giemsa staining, C-banding and fluorescence in situ hybridization with 18S rDNA (red signals, pairs 24) and 5S rDNA (green signals, pairs 20) probes. Ag-NORs sites and $\mathrm{CMA}_{3}+$ /DAPI- regions are highlighted in the boxes, evidencing size heteromorphism. Scale bar $=5 \mu \mathrm{m}$. 
The $18 \mathrm{~S}$ and $5 \mathrm{~S}$ rDNA sequences were mapped also at the same position in identical chromosomes in both species. The 18S rDNA sites are coincident with the Ag$\mathrm{NORs} / \mathrm{CMA}_{3}+$ /DAPI- signals (pair 24), while the $5 \mathrm{~S}$ rDNA sites are located in the pericentromeric region of pair 20.

\section{DISCUSSION}

Among Carangaria several families, like Centropomidae, Carangidae, Sphyraenidae, Coryphaenidae, Toxotidae, and Rachycentridae, have karyotypes mainly composed of $2 \mathrm{n}=48$ chromosomes (Accioly et al., 2012; Costa et al., 2015; Soares et al., 2017; Supiwong et al., 2017; Borges et al., 2019; Motta-Neto et al., 2019), while Pleuronectiformes (mainly Pleuronectodei), have chromosome numbers ranging from $2 n=26$ to $2 n=48$ (Azevedo et al., 2007; Arai, 2011). Most of the karyotype variations are due to pericentric inversions and Robertsonian translocations, which promote an increase of the NF (number of chromosome arms) and reduction of the diploid number, as well as increasing polymorphisms in a species, providing variation for natural selection and can even lead to speciation.

However, Polynemidae species still lacks cytogenetic data as a whole. Eleutheronema tetradactylum is the only species of this family with some cytogenetic information so far, revealing $2 \mathrm{n}=48$ acrocentric chromosomes (Khuda-Bukhsh and Barat, 1987). This is a frequent condition considered as basal in the Percomorpha (Galetti et al., 2000; Arai, 2011; Motta-Neto et al., 2019), thus suggesting that it may also represent the ancestral state of Polynemidae. Regardless, the two species now analyzed have an unexpected $2 \mathrm{n}=58$ chromosome number; in fact, this is the highest diploid value ever reported for a Carangaria group (Arai, 2011), thus constituting a likely autapomorphy for the family.

Multiple fissions have already been reported as impactful rearrangements in the karyotypic evolution of some fish species (Feldberg et al., 1993), but a very uncommon feature among Carangaria groups. As expected, such events lead to an increase in the diploid number and linkage groups. Assuming $2 n=48$ chromosomes as the basal condition for Polynemidae, we can estimate that at least five fission events have occurred during the karyotype evolution of $P$. virginicus and $P$. oligodon, thus resulting in their peculiar high diploid number and four microchromosome pairs. These small kind of chromosomes are also very uncommon in Carangaria species, which usually present a symmetrical arrangement, showing a gradual variation in size between the largest and the smallest chromosomes in karyotypes (Molina et al., 2014; Costa et al., 2016; Borges et al., 2019).

Studies on the dynamics and genomics of microchromosomes have identified many unique characteristics compared with those of macrochromosomes; these include their being guanine and cytosine (GC)-rich in most species. The high frequency of crossing over (recombination rates) has been attributed to the higher GC content and recombination hot spots, which ultimately provide stability during cell division, particularly during meiosis (Ezaz and Young, 2013). Although previous studies have characterized microchromosomes as inert heterochromatic elements, it is now well established that microchromosomes are functional chromosomes. As in sex and autosomal chromosomes, the presence of telomeres and a centromere is responsible for the stable inheritance of a microchromosome during cell division and can be inherited for many generations (Ezaz and Young, 2013). 
Similar to the Polynemidae, most Carangaria representatives exhibit unique rDNA regions with an independent arrangement of the $18 \mathrm{~S}$ and $5 \mathrm{~S}$ sites (Azevedo et al., 2005; Costa et al., 2015, 2016; Soares et al., 2014, 2017; Supiwong et al., 2017; Borges et al., 2019), a basal condition among teleost fishes (Gornung, 2013). It was already demonstrated that in several marine species the rDNA regions are implicated in chromosomal changes (Molina et al., 2002; Getlekha et al., 2018). Indeed, in some species for which the rDNA was further investigated, it was showed that it has a complex association with microsatellites, transposition elements, and histones (Costa et al., 2015). It is likely that these repetitive DNA arrays could support evolutionary instabilities (Coghlan et al., 2005), thus favoring chromosomal rearrangements. In fact, in some fish species with high diploid values (Morescalchi et al., 1992), transposable elements have had a significant role (Auvinet et al., 2018). However, this is still an open question to be later investigated in Polydactylus.

Another karyotypic feature that deserves additional comment in P. virginicus and $P$. oligodon refers to the polymorphism in the size of the nucleolar organizer regions. Numerical and size polymorphisms of the $18 \mathrm{~S}$ and $5 \mathrm{~S}$ rDNA sites are relatively frequent in marine percomorphs (e.g., Pisano and Ghigliotti, 2009), and, in some cases, the amplification of these sequences can even result in chromosomal fissions (Hall and Parker, 1995; Rousselet et al., 2000). However, the widespread occurrence of $2 n \leq 48$ chromosomes suggests that such a correlation does not occur in Carangaria and, in this sense, strengthening the exceptionality of the evolutionary pathway that has occurred in Polydactylus.

In addition to macro and microstructural chromosome congruences, the $2 \mathrm{n}=48$ acrocentric chromosomes of the threadfin E. tetradactylum (Khuda-Bukhsh and Barat, 1987), brings the karyotype pattern of Polynemidae closer to that of most Carangaria groups, except flatfishes Pleuronectiformes. Indeed, the available cytogenetic data for some of the 15 families that make up the flatfish clade (Campbell et al., 2019), indicate a marked trend to reduce the $2 \mathrm{n}(28-48)$ and to increase the NF values (Arai, 2011), a peculiar attribute of this group assigned to Robertsonian fusions and pericentric inversions (Azevedo et al., 2005, 2007). Moreover, its single chromosome pair carrying rDNA sequences have undergone conspicuous reorganizations, as shown by the low inter- and intra-genera homology its presents (Azevedo et al., 2005). These contrasting chromosome patterns between Polynemidae and flatfishes indicate that since their remote ancestry (Alfaro et al., 2018), a larger set of chromosome changes have differentially modulated the evolutionary history of the later ones.

In conclusion, the similar karyotype organization between both Polydactylus species now investigated, as well as its absence in their co-familiar species and also other probable related groups, can be explained as a byproduct of recent evolutionary divergence among lineages. In fact, as a whole, the karyotypes of Polynemidae species reveal a remarkable mosaic of characteristics within the Carangaria group. Some of these features are preserved and shared with close relatives, as found in $E$. tetradactylum. Besides other derived features, as the highest diploid number and the occurrence of microchromosomes appear, at this time, as exclusive ones of $P$. virginicus and P. oligodon. 


\title{
ACKNOWLEDGMENTS
}

We are grateful to the Conselho Nacional de Desenvolvimento Científico e Tecnológico (CNPq) (Process \#442664/2015-0) for financial support, and for research grants to ATB, RXS and GWWFC. We also thank the Chico Mendes Institute for Biodiversity Conservation (ICMBio) for permission to collect, and José Garcia Júnior for taxonomic identification of the species.

\section{CONFLICTS OF INTEREST}

\author{
The authors declare no conflict of interest.
}

\section{REFERENCES}

Accioly IV, Bertollo LAC, Costa GWWF, Jacobina U, et al. (2012). Chromosomal population structuring in carangids (Perciformes) between the north-eastern and south-eastern coasts of Brazil. Afr. J. Mar. Sci. 34: 383-389.

Alfaro ME, Faircloth BC, Harrington RC, Sorenson L, et al. (2018). Explosive diversification of marine fishes at the Cretaceous-Palaeogene boundary. Nat. Ecol. Evol. 2: 688-696.

Arai R (2011). Fish Karyotypes: a check list. Springer, Tokyo.

Auvinet J, Graça P, Belkadi L, Petit L, et al. (2018). Mobilization of retrotransposons as a cause of chromosomal diversification and rapid speciation: the case for the Antarctic teleost genus Trematomus. BMC Genomics. 19: 339.

Azevedo MFC, Oliveira C, Pardo BG, Martinez P, et al. (2005). Chromosome banding and 18S rDNA in situ hybridization analysis of seven species of the family Achiridae (Teleostei: Pleuronectiformes). Genetica. 125: 125132.

Azevedo MFC, Oliveira C, Pardo BG, Martinez P, et al. (2007). Cytogenetic characterization of six species of flatfishes with comments to karyotype differentiation patterns in Pleuronectiformes (Teleostei). J. Fish Biol. 70: 1-15.

Betancur-R R, Broughton RE, Wiley EO, Carpenter K, et al. (2013a). The tree of life and a new classification of bony fishes. PloS Curr. 1st ed.

Betancur-R R, Li C, Munroe TA, Ballesteros JA, et al. (2013b). Addressing gene tree discordance and non-stationarity to resolve a multi-locus phylogeny of the flatfishes (teleostei: Pleuronectiformes). Syst. Biol. 62: 763-785.

Borges AT, Cioffi MB, Bertollo LAC, Soares RX, et al. (2019). Paracentric inversions differentiate the conservative karyotypes in two Centropomus species (Teleostei: Centropomidae). Cytogenet. Genome Res. 157: 239-248.

Campbell MA, Chanet B, Chen J-N, Lee M-Y, et al. (2019). Origins and relationships of the Pleuronectoidei: Molecular and morphological analysis of living and fossil taxa. Zool. Scr. 48: 640-656.

Carpenter KE (2002). The living marine resources of the Western Central Atlantic.Volume 3: Bony fishes part 2 (Opistognathidae to Molidae), sea turtles and marine mammals. FAO Species Identification Guide for Fishery Purposes and American Society of Ichthyologists and Herpetologists Special Publication No. 5. Rome, p. 13752127.

Cioffi MB, Moreira-Filho O, Ráb P, Sember A, et al. (2018). Conventional cytogenetic approaches - useful and indispensable tools in discovering fish biodiversity. Curr. Genet. Med. Rep. 6: 176-186.

Coghlan A, Eichler EE, Oliver SG, Paterson AH, et al. (2005). Chromosome evolution in eukaryotes: a multi-kingdom perspective. Trends Genet. 21: 673-682.

Costa, GWWF, Cioffi MB, Bertollo LAC and Molina WF (2015). Structurally complex organization of repetitive DNAs in the genome of cobia (Rachycentron canadum). Zebrafish. 12: 215-220.

Costa GWWF, Cioffi MB, Bertollo LAC and Molina WF (2016). The evolutionary dynamics of ribosomal genes, histone H3, and transposable Rex elements in the genome of Atlantic snappers. J. Hered. 107: 173-180.

Ezaz T and Young M (2013). Microchromosomes. In: Brenner's Encyclopedia of Genetics (Maloy S and Hughes K, eds.). 2nd edition. Academic Press, Waltham.

Feldberg E, Porto JI, Nakayama CM and Bertollo LAC (1993). Karyotype evolution in Curimatidae (Teleostei, Characiformes) from the Amazon region. II. Centric fissions in the genus Potamorhina. Genome. 36: 372-376.

Fricke R, Eschmeyer WN and Fong JD (2020). Species by Family/Subfamily, available at [http://researcharchive.calacademy.org/research/ichthyology/catalog/SpeciesByFamily.asp]. Acessed 01 March 2020.

Froese R and Pauly D (2020). FishBase, www.fishbase.org (06/2020).

Galetti PM, Aguilar CT and Molina WF (2000). An overview of marine fish cytogenetics. Hydrobiologia. 420: 55-62. 
Getlekha N, Cioffi MD, Maneechot N, Bertollo, LA, et al. (2018). Contrasting evolutionary paths among Indo-Pacific Pomacentrus species promoted by extensive pericentric inversions and genome organization of repetitive sequences. Zebrafish. 15: 45-54.

Gold JR, Lee C, Shipley NS and Powers PK (1990). Improved methods for working with fish chromosomes with a review of metaphase chromosome banding. J. Fish Biol. 37: 563-575.

Gornung E (2013). Twenty years of physical mapping of major ribosomal RNA genes across the Teleosts: A review of research. Cytogenet. Genome Res. 141:90-102.

Gosline WA (1968). The suborders of perciform fishes. Proc. US Natl. 124:1-78.

Hall KJ and Parker JS (1995). Stable chromosome fission associated with rDNA mobility. Chromosome Res. 3: 417-422.

Harrington RC, Faircloth BC, Eytan RI, Smith WL, et al. (2016). Phylogenomic analysis of carangimorph fishes reveals flatfish asymmetry arose in a blink of the evolutionary eye. BMC Evol. Biol. 16: 224.

Howell WM and Black DA (1980). Controlled Silver-staining of nucleolus organizer regions with a protective colloidal developper a 1-step method. Experientia. 36: 1014-1015.

Hughes LC, Ortí G, Huang Y, Sun Y, et al. (2018). Comprehensive phylogeny of ray-finned fishes (Actinopterygii) based on transcriptomic and genomic data. PNAS. 115: 6249-6254.

Johnson GD (1993). Percomorph phylogeny: progress and problems. Bull. Mar. Sci. 52: 3-28.

Kang S, Imamura H and Kawai T (2017). Morphological evidence supporting the monophyly of the family Polynemidae (Teleostei: Perciformes) and its sister relationship with Sciaenidae. Ichthyol. Res. 65: 29-41.

Khuda-Bukhsh AR and Barat A (1987). Chromosomes in fifteen species of Indian teleosts (Pisces). Caryologia. 40: 131 144.

Levan A, Fredga K and Sandberg A (1964). Nomenclature for centromeric position on chromosomes. Hereditas. 52: 201-220.

Menezes NA and Figueiredo JL (1985). Manual de peixes marinhos do sudeste do Brasil. V. Teleostei (4). Museu de Zoologia, Universidade de São Paulo, Brazil.

Molina WF and Galetti Jr PM (2002). Robertsonian rearrangements in the reef fish Chromis (Perciformes, Pomacentridae) involving chromosomes bearing 5S rRNA genes. Genet. Mol. Biol. 25: 373-377.

Molina WF, Alves DEO, Araujo WC, Martinez PA, et al. (2010). Performance of human immunostimulating agents in the improvement of fish cytogenetic preparations. Genet. Mol. Res. 9: 1807-1814.

Molina WF, Martinez PA, Bertollo LAC and Bidau CJ (2014). Evidence for meiotic drive as an explanation for karyotype changes in fishes. Mar. Genomics. 15: 29-34.

Morescalchi A, Pisano E, Stanyon R and Morescalchi MA (1992). Cytotaxonomy of Antarctic teleosts of the Pagothenia/Trematomus complex (Nototheniidae, Perciformes). Polar Biol. 12: 553-558.

Motta-Neto CC, Cioffi MB, Costa GWWF, Amorim KDJ, et al. (2019). Overview on karyotype stasis in Atlantic grunts (Eupercaria, Haemulidae) and the evolutionary extensions for other marine fish groups. Front. Mar. Sci. 6: 1-12.

Motomura H (2004). Threadfins of the world. An annotated and illustrated catalogue of polynemid species known to date. Family Polynemidae. FAO Species Catalogue for Fishery Purposes. No 3, FAO, Rome.

Nelson JS, Grande TC and Wilson MV (2016). Fishes of the World. John Wiley \& Sons, New Jersey.

Pendás AM, Morán P, Freije JP and Garcia-Vásquez E. (1994). Chromosomal location and nucleotide sequence of two tandem repeats of the Atlantic salmon 5S rDNA. Cytogenet. Genome Res. 67: 31-36.

Pinkel D, Straume T and Gray JW (1986). Cytogenetic analysis using quantitative, high-sensitivity, fluorescence hybridization. PNAS. 83: 2934-2938.

Pisano E and Ghigliotti L (2009). Ribosomal genes in notothenioid fishes: focus on the chromosomal organization. Mar. Genomics. 2: 75-80.

Presti P, Johnson GD and Datovo A (2020). Facial and gill musculature of polynemid fishes, with notes on their possible relationships with sciaenids (Percomorphacea: Perciformes). J. Morphol. 281: 662-675.

Rousselet J, Monti L, Auger-Rozenberg MA, Parker JS, et al. (2000). Chromosome fission associated with growth of ribosomal DNA in Neodiprion abietis (Hymenoptera: Diprionidae). Proc. Biol. Sci. 267: 1819-1823.

Sanciangco MD, Carpenter KE and Betancur-R R (2015). Phylogenetic placement of enigmatic percomorph families (Teleostei: Percomorphaceae). Mol. Phylogenet. Evol. 94: 565-576.

Schweizer D (1976). Reverse fluorescent chromosome banding with chromomycin and DAPI. Chromosoma. 58: 307324.

Soares RX, Bertollo LAC, Cioffi MB, Costa GWWF, et al. (2014). Chromosomal distribution of two multigene families and the unusual occurrence of an X1X1X2X2/X1X2Y sex chromosome system in the dolphinfish (Coryphaenidae): an evolutionary perspective. Genet. Mol. Res. 13: 2470-2479.

Soares RX, Cioffi MB, Bertollo LAC, Borges AT, et al. (2017). Chromosomal evolution in large pelagic oceanic apex predators, the barracudas (Sphyraenidae, Percomorpha). Genet. Mol. Res. 16: 10.4238/gmr16029644.

Sumner AT (1972). A simple technique for demonstrating centromeric heterochromatin. Exp. Cell. Res. 75: 304-306.

Supiwong W, Jiwyam W, Sreeputhorn K, Maneechot N, et al. (2017). First report on classical and molecular cytogenetics of archerfish, Toxotes chatareus (Perciformes: Toxotidae). Nucleus. 60: 349-359. 
White TJ, Bruns T, Lee S and Taylor J (1990). Amplification and direct sequencing of fungal ribosomal RNA genes for phylogenetics. In: PCR Protocols: A Guide to Methods and Applications (Innis M, Gelfand D, Sninsky J and White T, eds.). Academic Press Inc, Orlando. 